\title{
NBIC-convergence in production systems
}

\author{
Antonina Pahomova ${ }^{1}$, Sandor Halasz ${ }^{2}$, Vladimir Fedorchuk ${ }^{1}$, Galina Zelenkova ${ }^{3, *}$, and \\ Alexander Pakhomov ${ }^{4}$ \\ ${ }^{1}$ Platov South-Russian State Polytechnic University (NPI), 346428, 132, str. Prosveshcheniya, Novo- \\ cherkassk, Russia \\ ${ }^{2}$ Budapest University of Technology and Economics, 1111, Müegyetem rakpart 1-6, Budapest, Hun- \\ gary \\ ${ }^{3}$ Don State Technical University, 344003, sq. Gagarina, 1, Rostov-on-Don, Russia \\ ${ }^{4}$ Don State Agrarian University, 346493, o. Persianovsky, Russia
}

\begin{abstract}
The paper reveals the current problems of production systems, their lack of readiness to function in the conditions of application and development of NBIC technologies. The methodological basis of the research consists of fundamental works and modern scientific and practical developments of national and foreign scientists on the problems of creation and functioning of production, technological and socio-economic systems in the conditions of development using NBIC technologies. The research was carried out using such general scientific and special methods as: historicaldialectical and abstract-logical; comparative-analytical and system analysis; synthesis of scientific approaches. The authors prove the need to create a new system paradigm. The new paradigm of production systems that realize the potential of NBIC technologies is based on a concept that finds its concrete expression, firstly, in the initial or original concepts, and secondly, in the system of basic principles, laws, or sufficiently plausible hypotheses. It is these elements that make up the conceptual core of the paradigm, and efforts should be directed to their search and justification when forming a new paradigm. The paper analyzes the main methods and tools for implementing a new approach to the design of production systems.
\end{abstract}

\section{Introduction}

Research on the definitions of "production", "technical", "social", "economic", and "organizational" systems has been going on for decades. Different scientists in different periods of time, taking into account the achievements of scientific and technological progress and economic development, approached these concepts differently, offering different approaches to their research, tools, management methods and methodology. After conducting research on the scientific search for scientists, they can note the key elements of a particular time. Currently, NBIC technologies are such a key element. In their research, the authors reflect the impact of NBIC technologies on systems at various levels, with particular emphasis on production and socio-economic systems.

\footnotetext{
Corresponding author: zelenkovalex@rambler.ru
} 
The history of production systems begins with the first community labor collectives. Having a primitive structure, constantly evolving together with the tasks that a person sets, having reached today a complex multi-network structure with thousands of elements [1-17].

\section{Methods}

The methodological basis of the research consists of fundamental works and modern scientific and practical developments of national and foreign scientists on the problems of creation and functioning of production, technological and socio-economic systems in the conditions of development using NBIC technologies. The research is carried out using such general scientific and special methods as: historical-dialectical and abstract-logical (for generalization of transformational characteristics of production and socio-economic systems); comparative-analytical and system analysis (for the study of methodological approaches to the regulation of evolutionary processes); synthesis of scientific approaches (for the formation of conceptual positions).

\section{Results}

As part of our research, we rely on the scientific works of scientists presented in table 1, highlighting the key characteristics of production systems, such as the purpose, functions, resources and result of functioning.

Table 1. Comparative characteristic of concepts and approaches to defining the production system

\begin{tabular}{|c|c|c|c|c|}
\hline \multirow{2}{*}{$\begin{array}{l}\text { Author, } \\
\text { source }\end{array}$} & \multicolumn{4}{|c|}{ Characteristics of the PS as presented by the author } \\
\hline & $\begin{array}{l}\text { Considered sys- } \\
\text { tem }\end{array}$ & $\begin{array}{c}\text { Aims and functions of } \\
\text { system }\end{array}$ & $\begin{array}{c}\text { Resources under } \\
\text { study }\end{array}$ & $\begin{array}{l}\text { System per- } \\
\text { formance } \\
\text { results }\end{array}$ \\
\hline 1 & 2 & 3 & 4 & 5 \\
\hline V.N. Vyatkin & Industrial & $\begin{array}{l}\text { The implementation of } \\
\text { the joint work }\end{array}$ & Material, labor & Final product \\
\hline George Riggs & Industrial & $\begin{array}{l}\text { The implementation of } \\
\text { the process of receiving }\end{array}$ & Not specified & Useful products \\
\hline $\begin{array}{lr}\text { V.A. } & \text { Petrov, } \\
\text { A.N. } & \text { Maslen- } \\
\text { nikov } & \\
\end{array}$ & Flexible industrial & Program and target & $\begin{array}{l}\text { Material, energy, } \\
\text { labor }\end{array}$ & $\begin{array}{l}\text { Tangible end } \\
\text { results }\end{array}$ \\
\hline Yu.G. Kozyrev & $\begin{array}{l}\text { Complex industri- } \\
\text { al }\end{array}$ & Not specified & $\begin{array}{l}\text { Objects related by } \\
\text { cause and effect }\end{array}$ & $\begin{array}{l}\text { Products of a } \\
\text { certain quality }\end{array}$ \\
\hline $\begin{array}{l}\text { S.E. Khacha- } \\
\text { turov }\end{array}$ & Industrial & $\begin{array}{l}\text { Optimal resource devel- } \\
\text { opment }\end{array}$ & $\begin{array}{l}\text { Material, energy, } \\
\text { information }\end{array}$ & $\begin{array}{l}\text { Specific bene- } \\
\text { fits }\end{array}$ \\
\hline $\begin{array}{l}\text { V.B. } \\
\text { Voytsekhov- } \\
\text { sky. }\end{array}$ & Industrial & $\begin{array}{l}\text { Element depreciation, } \\
\text { cost minimization }\end{array}$ & $\begin{array}{lr}\text { Elements } & \text { with } \\
\text { different } & \text { service } \\
\text { lives } & \\
\end{array}$ & Final product \\
\hline N.V. Kazakova & Industrial & Entrepreneurial & Related elements & $\begin{array}{l}\text { Finished prod- } \\
\text { uct }\end{array}$ \\
\hline $\begin{array}{l}\text { V.L. Belousov, } \\
\text { V.E. Vershin }\end{array}$ & $\begin{array}{l}\text { Production and } \\
\text { sales }\end{array}$ & $\begin{array}{l}\text { Obtaining, converting, } \\
\text { and using energy }\end{array}$ & Energy & Energy \\
\hline $\begin{array}{l}\text { A.A. Kolobov, } \\
\text { I.I. Omelchen- } \\
\text { ko }\end{array}$ & $\begin{array}{l}\text { Production and } \\
\text { sales }\end{array}$ & $\begin{array}{l}\text { Production, sales, service } \\
\text { support }\end{array}$ & $\begin{array}{l}\text { Material, } \\
\text { information }\end{array}$ & $\begin{array}{lr}\begin{array}{l}\text { Ensuring } \\
\text { product }\end{array} & \text { of } \\
\text { cycle } & \end{array}$ \\
\hline K.K. Valtukh & $\begin{array}{l}\text { Anthroposphere } \\
\text { industrial }\end{array}$ & $\begin{array}{l}\text { Self-replication of its } \\
\text { components }\end{array}$ & $\begin{array}{l}\text { Material, energy, } \\
\text { information }\end{array}$ & Useful products \\
\hline $\begin{array}{l}\text { Yu.Ya. } \\
\text { Eleneva }\end{array}$ & Business-system & $\begin{array}{lr}\text { Improving } & \text { business } \\
\text { competitiveness } & \text { and } \\
\text { value } & \\
\end{array}$ & $\begin{array}{l}\text { Information, labor, } \\
\text { capital, land }\end{array}$ & Useful products \\
\hline
\end{tabular}




\begin{tabular}{|l|l|l|l|l|}
\hline $\begin{array}{l}\text { O.V. Krivano- } \\
\text { va }\end{array}$ & $\begin{array}{l}\text { Production organ- } \\
\text { izational }\end{array}$ & $\begin{array}{l}\text { Receiving, converting, } \\
\text { and transmitting infor- } \\
\text { mation }\end{array}$ & $\begin{array}{l}\text { Material objects, } \\
\text { personnel }\end{array}$ & Not specified \\
\hline G.B. Kleyner & Company & Production activity & $\begin{array}{l}\text { Material, infor- } \\
\text { mation }\end{array}$ & Useful products \\
\hline I.V. Druzhinin & Industrial & $\begin{array}{l}\text { Active interaction with } \\
\text { the competitive envi- } \\
\text { ronment }\end{array}$ & $\begin{array}{l}\text { Material, infor- } \\
\text { mation }\end{array}$ & Useful products \\
\hline Yu.M. Soldak & Industrial & $\begin{array}{l}\text { Effective target conver- } \\
\text { sion of resources }\end{array}$ & Material, labor & $\begin{array}{l}\text { Tangible assets } \\
\text { and services }\end{array}$ \\
\hline
\end{tabular}

In our opinion, the most general is the definition of production systems given by Yu.M. Soldak as "..a set of many elements aimed at the most effective implementation of the production process in accordance with a given goal". In addition, the paper emphasizes that the goal of any production system is to create "a specific product, expressed in details, product, in the totality of actions performed to create material values, which are also united by the concept of "services", etc....". This concept does not limit the number of elements and at the same time highlights the production process, without which there can be no production system, as well as the elements necessary for its flow.

An important feature of the production system according to Yu.M. Soldak is the availability of resources. All of the properties that characterize the production system are of a strategic nature. It is the availability of the entire range of resources that allows the production process to be carried out, as a result of which qualitative and quantitative changes lead to the accumulation process.

In our opinion, the definition of Yu.M. Soldak, given in relation to the conditions of machine production (human-machine systems), now needs some clarifications that would more accurately reflect modern features, namely the convergence of NBIC technologies.

In addition, in these works, the author considers the production system as a previously created object that needs to be improved based on the changing external environment and the interests of society. In other words, the operating conditions of the production system are set from the outside. In our opinion, this approach is not quite correct, as currently the task is to design and create production systems that ensure the convergence of NBIC technologies.

It is more logical to consider the production process as a condition for ensuring the key goals of society, without which its strategic development is impossible, and production systems are a means of implementing various production processes that ensure the convergence of NBIC technologies

The works of I.V. Druzhinin are devoted to the need to build a generalized paradigm of production systems and a theoretical model is proposed as a system that actively interacts with the competitive environment, has activity, needs, technologies, which in the process of interacting with the environment takes resources from the latter, and gives the environment the results it produces (carries out resource exchange with the environment (Fig. 1).

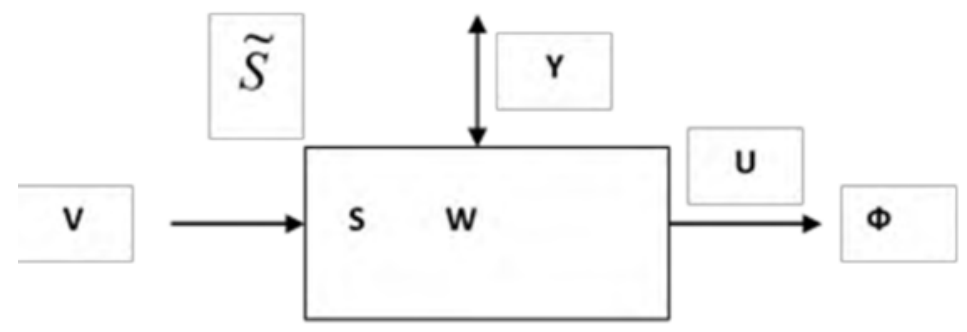

$\mathrm{S}$ - production system; $\hat{\mathrm{S}}$ - competitive environment; $\Phi$ - competitive environment activity; $\mathrm{Y}$ - the needs of the competitive environment; $\mathrm{W}$ - technologies; $\mathrm{V}$ - resources; $\mathrm{U}$ - production results. 
Fig. 1. Production systems paradigm model (I.V. Druzhinin).

Our research has shown that the development and use of NBIC technologies requires the creation of a new paradigm of production systems. In the light of the above, we propose the following definition: "a production system is a multidimensional and convergent system that includes systemically related elements of different quality and different technologies that ensure the transformation of knowledge, skills and resources into factors of production in order to obtain artificial objects that can meet the strategic goals of a person and society. Production systems interact with the external environment within its limitations, and their goals are supported by achieving the goals of measures to manage its functioning and development".

Obviously, this definition significantly expands the scope of the "production system" category: it can also include all objects of material production and systems that operate and implement NBIC technologies.

This definition of the production system will allow unifying sufficiently approaches to the assessment and management of various production systems that operate in various spheres of society, but are very closely related to each other.

\section{Discussion}

The term "paradigm", which is widely used in the methodology of science, is used in various senses. In the future, we will understand the paradigm as a conceptual scheme for the formation of approaches to the formulation of problems characteristic of various production systems implementing NBIC technologies, determining the directions and ways to solve them; the methodological basis for the research and design of such production systems.

It is obvious that such a paradigm should be based on a fundamental theory that dominates in a certain period of time. With the development of science, deeper and more general theories appear, which become new paradigms, although the old paradigms are not completely discarded, but the boundaries of their application are more clearly outlined. It is also widely believed that the new paradigm, like the more fundamental theory in general, contains the old one as a particular, or limiting, case.

In our opinion, the new paradigm of production systems that realize the potential of NBIC technologies should be based on some general idea or concept that finds its specific expression, firstly, in the initial or original concepts, and secondly, in a system of basic principles, laws, or sufficiently plausible hypotheses. It is these elements that make up the conceptual core of the paradigm, and efforts should be directed to their search and justification when forming a new paradigm.

Research has shown that the process of forming a new paradigm can be presented in the form of a flowchart shown in figure 2 . 


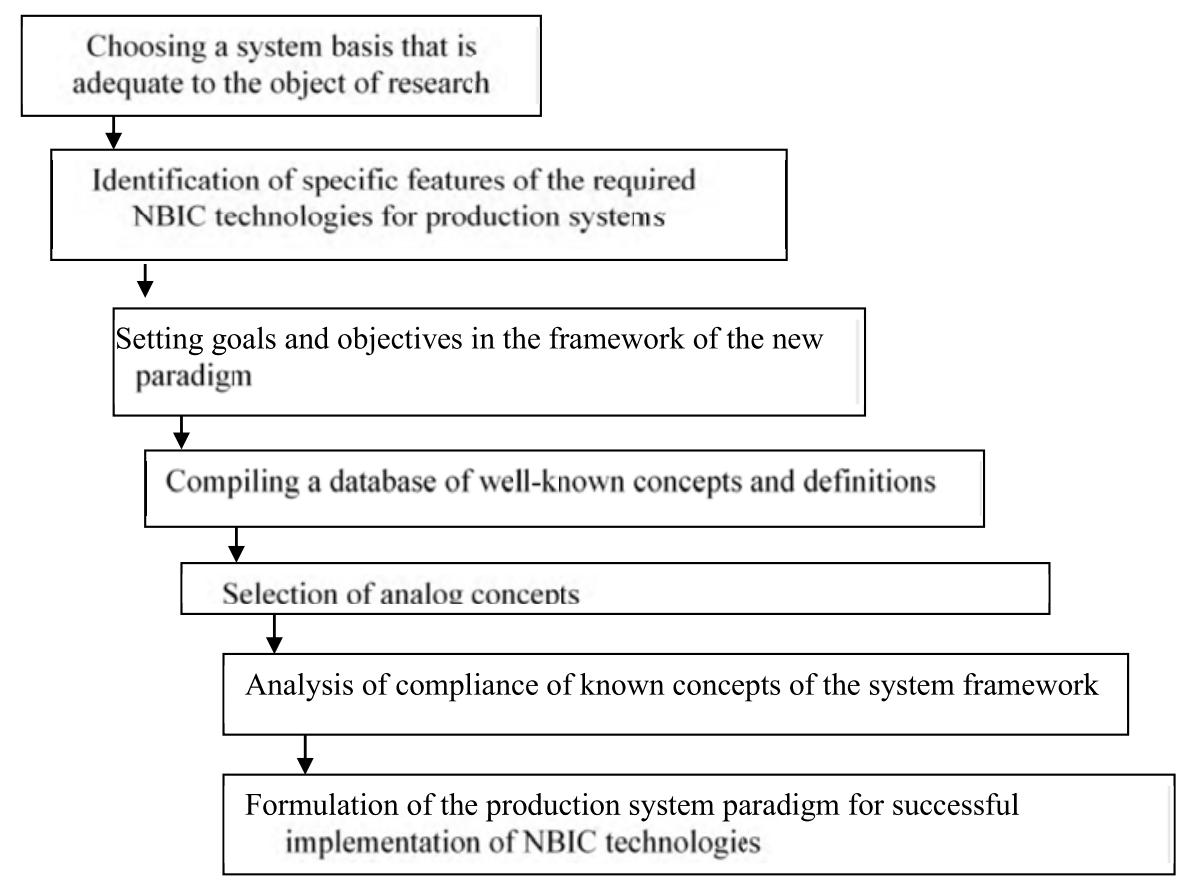

Fig. 2. The main elements of the flowchart for forming a new paradigm of the production system that ensures the convergence of NBIC technologies

One of the elements of the process of forming a new paradigm of successfully implementing NBIC technologies in production systems is to harmonize the interests of all participants, reduce the risks and threats facing modern society the authors consider it necessary to design human-oriented production systems.

In accordance with the Order of the Federal Agency for Technical Regulation and Metrology dated November 29, 2012 No. 1290-st GOST R ISO 9241-210-2012 "Ergonomics of human-system interaction. Part 210. Human-oriented design of interactive systems", human-oriented design is a method of developing interactive systems aimed at creating usable and useful systems that take into account the characteristics of users and their needs based on ergonomic principles. This approach increases the effectiveness, efficiency, availability and sustainability of systems, user satisfaction and productivity, and prevents possible adverse effects of using systems on human health and safety. This document defines the principles and main elements of planning.

Research has shown that it is advisable to supplement the human-oriented design of production systems with additional components. Taking into account the specifics and complexity of NBIC technologies, using key elements (nano -, bio -, information and cognitive technologies), it is advisable to use the following methods: synergy, MFS, RUP, DSDM, SCRUM, Agile, TAA, etc. in each unique production system. Research shows the need to reorient management functions in the design of production systems based on the following basic principles: diagnostics of the production state, operational planning of individual elements of the required NBIC technologies, arrangement of control of NBIC technologies (table 2). 
Table 2. Operational management model for designing production systems at implementing NBIC technologies

\begin{tabular}{|c|c|}
\hline $\begin{array}{c}\text { Diagnostics of the pro- } \\
\text { duction system state }\end{array}$ & $\begin{array}{l}\text { Technical and technological state, analysis of re- } \\
\text { source costs for production, economic performance indica- } \\
\text { tors }\end{array}$ \\
\hline $\begin{array}{c}\text { Operational planning of } \\
\text { individual elements of required } \\
\text { NBIC technologies }\end{array}$ & $\begin{array}{l}\text { Drawing up a balance of material, technical and fi- } \\
\text { nancial resources necessary for the successful implementa- } \\
\text { tion of the NBIC-technology production system, determining } \\
\text { sources of financing, evaluating the effectiveness of invest- } \\
\text { ment projects, etc. }\end{array}$ \\
\hline $\begin{array}{c}\text { Arrangement of control } \\
\text { of NBIC technologies }\end{array}$ & $\begin{array}{l}\text { Completion of target tasks, distribution of material } \\
\text { and technical resources and personnel, status of task comple- } \\
\text { tion in accordance with current conditions, etc. }\end{array}$ \\
\hline
\end{tabular}

\section{Conclusion}

At the same time we consider it necessary to note that for successful design of efficient human-oriented production system functioning in the conditions of development of NBICtechnologies created to achieve the goals of socio-economic system, to minimize emerging risks and threats, it is necessary to develop and use a holistic institutional tools related to the gradual transformation of the system paradigm of knowledge. In terms of development of NBIC-technologies, various scholars stand out as positive (technological breakthroughs, the changing technological structure, the high speed development of economy, high efficiency, advances in science allow to radically improve the socio-economic component of social life increase the life, welfare, availability of benefits, etc.) and negative (an even bigger gap between the development of economies of different countries, social stratification, environmental degradation, loss of control over artificial intelligence, cyber literacy and infringement of the rights and freedoms of the individual, etc.), opportunities, risks and threats. The production system is one of the components of the socio-economic system that is in dynamic balance with internal and external factors. Scientific and technological progress since the beginning of the history of human development has not stopped despite various political, economic, social and other changes in society. According to the authors, the development of NBIC technologies, their strengthening and interaction, development and combination, and the formation of new interdisciplinary sciences are the nearest future of the socio-economic system. At the same time, the implementation of NBIC technologies in the modern socio-economic system has a number of unresolved aspects. Neither social, nor economic, nor any other system is fully ready to implement and manage the potential of NBIC technologies, which leads to non-realization of the potential and their targeted use. In order to achieve the set goals and reduce the risks and threats that have arisen, systemic institutional transformations of the socio-economic system are necessary, changing the existing system paradigm of knowledge.

The reported study was funded by RFBR and FRLC, project number 20-510-23002 "The development of Janos Kornai's system paradigm is the fundamental basis for the creation of production and technical systems in the conditions of NBIC convergence".

\section{References}


1. H. Markram, E. Muller, S. Ramaswamy, M. Reimann, M. Abdellah, Cell, 163, 456-492 (2015)

2. E. Kolbachev, Sh. Khalas, V. Fedorchuk, Bulletin of the South Russian State Polytechnic University (NPI). Series: Social and economic sciences, 4, 36-43 (2019)

3. S. Halasz, P. Stumpf, IEEE Transactions on Industry Applications, 54, 3393-3404 (2018)

4. A. Zelenkov, A. Ermakov, G. Zelenkova, et al., E3S Web of Conferences, 135, 01088 (2019)

5. A. Zelenkov, A. Ermakov, G. Zelenkova et al., IOP Conf. Series: Earth and Environmental Science, 403, 012020 (2019)

6. A. Zelenkov, G. Zelenkova, A. Ermakov et al., E3S Web of Conferences, 164, 06032 (2020)

7. K. Suenaga, Technology in Society, 57, 135-141 doi:https://doi.org/10.1016/j.techsoc.2018.12.010

8. H. Kang, J. Lee, S. Choi, H. Kim, J. Park, J. Son, B. Kim, S. Noh, International Journal of Precision Engineering and Manufacturing-Green Technology, 3 (2016) doi:https://doi.org/10.1007/s40684-016-0015-5

9. S. Newman, Z. Zhu, V. Dhokia, A. Shokrani, CIRP Annals - Manufacturing Technology, 64 (2015) doi: http://dx.doi.org/10.1016/j.cirp.2015.04.109

10. R. Yakovenko, A. Savost'yanov, G. Narochniy, V. Soromotin, I. Zubkov, O. Papeta, R. Svetogorov, S. Mitchenko, Catalysis Science \& Technology (2020) doi:https://doi.org/10.1039/D0CY00975J

11. E. Kristoffersena, F. Blomsmab, P. Mikalefa, J. Lia, Journal of Business Research, 120, 241-261 (2020) doi:https://doi.org/10.1016/j.jbusres.2020.07.044

12. D. D’Amico, J. Ekoyuncu, S. Addepalli, C. Smith, E. Keedwell, J. Sibson and S. $\begin{array}{lllll}\text { Penver, } & \text { Procedia } & \text { CIRP, } & \text { 86, } & \end{array}$ doi:https://doi.org/10.1016/j.procir.2020.01.043

13. T. Bikmukhametov, J. Jäschke, Computers and Chemical Engineering, 138, (2020) doi:https://doi.org/10.1016/j.compchemeng.2020.106834.

14. J. Zhou, P. Li, Y. Zhou, B. Wang, J. Zang, L. Meng, Engineering, 4(1), (2018) doi:https://doi.org/10.1016/j.eng.2018.01.002

15. L. Ávila, L. Teixeira, P. Almeida, International Journal of Industrial Engineering and Management, 9(3), (2018) doi:http://doi.org/10.24867/IJIEM-2018-3-121.

16. B. Zhou, Z. Li and C. Chen, Minerals, 2, (2017) doi:http://dx.doi.org/10.3390/min7110203

17. M. Glatta, C. Sinnwella, L. Yia, S. Donohoeb, B. Ravanib, J. C. Auricha, Journal of Manufacturing Systems (2020) doi:https://doi.org/10.1016/j.jmsy.2020.04.015 